\title{
AN IMPROVEMENT OF MECHANISMS OF THE REGULATION OF LEGAL RELATIONS IN THE FIELD OF TECHNOLOGY TRANSFER UNDER CONDITIONS OF THE INTEGRATION OF UKRAINE INTO THE EU
}

\section{УДОСКОНАЛЕННЯ МЕХАНІЗМІВ ВРЕГУЛЮВАННЯ ПРАВОВІДНОСИН У СФЕРІ ТРАНСФЕРУ ТЕХНОЛОГІЙ В УМОВАХ ІНТЕГРАЦІЇ УКРАЇНИ В ЄС}

\section{Tamara Yaroshevska ${ }^{1}$}

DOI: https://doi.org/10.30525/978-9934-588-53-2-43

Abstract. The purpose of the article is to substantiate proposals aimed at improving the legislation of Ukraine in the field of technology transfer, taking into account an existing European experience in this field. The research is based on an analysis of the legislation of European countries and certain leading foreign countries, the practice of their application of norms. As a result of this research it was found that the necessary conditions for an activation of innovative processes in Ukraine is a carrying out a set of measures, among which the technology transfer system occupies an important place. However, the negative effects of the crisis in Ukraine's economy and the significant reduction of tax incentives for technology transfer have made it much more difficult to conduct research and development and introduce new technologies into production in Ukraine. It is proved that an analysis of the EU legislation in the field of scientific research allows identifying priority areas for the development of modern innovation activity, including the formation of a single economic and legal space and the market of high-tech products. It is established that one of the main mechanisms for implementing the policy of stimulating innovative scientific and technological processes in the EU is the development and implementation of framework programs. In the context of globalization, this approach allows EU member states

${ }^{1}$ Candidate of Legal Sciences, Associate Professor,

Associate Professor of the Department of Civil Law Disciplines,

Dnipropetrovsk State University of Internal Affairs, Ukraine 
to have a high level of economic competitiveness, and mutual integration within the EU promotes the development of partnerships between countries and the use of combined innovation, scientific and technical potential. Ukraine has now become an associate member of the largest EU Framework Programme for Research and Innovation "Horizon 2020". The signing of the Agreement on participation of Ukraine in the EU program «Horizon 2020» contributes to the expansion of participation of Ukrainian research organizations and universities in European scientific research, as well as the development of partnership relations between Ukraine and the EU. In order to create favorable conditions for innovation activity and use of industrial property right objects in the EU single space, the author of the article proposes ways to improve the mechanism of legislative regulation of technology transfer in Ukraine, taking into account the existing European experience in this sphere.

\section{1. Ветуп}

Актуальність теми дослідження зумовлена подальшою глобалізацією світової економіки, швидким розвитком міжнародної торгівлі та промисловості, потребою створення ефективних механізмів охорони та впровадження об'єктів права інтелектуальної та, зокрема, промислової власності. В умовах світової інтеграції, посилення конкуренції на світових ринках рівень економічного розвитку країни визначається науково-технічним потенціалом та здатністю до впровадження об'єктів права промислової власності. Можна стверджувати, що передача технологій є основним чинником зростання обсягу виробництва і продуктивності праці та сприяє підвищенню якості створеної нової продукції. Тому однією з найважливіших складових інноваційного процесу і перспективним механізмом економічної стабілізації держави $€$ трансфер технологій. Трансфер технологій відіграє значну роль в економічному та інноваційному розвитку кожної провідної країни, в тому числі й в Україні. Безперечно, трансфер технологій як сучасний засіб впровадження інновацій на підприємстві надає можливість прискорити та вдосконалити процес виробництва, підняти рівень конкурентоспроможності товарів, а належне фінансування і регулювання цієї сфери в довгостроковій перспективі відкриває перед країнами можливість вийти у світові промислові лідери. 
У провідних країнах світу механізми трансферу технологій вже давно працюють і продовжують далі вдосконалюватися, тоді як в Україні цей процес ще знаходиться на стадії зародження і вимагає деталізованого опрацювання. Тому Україні важливо вивчити досвід провідних закордонних країн щодо правового врегулювання відносин у сфері трансферу технологій і виявити позитивні напрацювання, які можна було б запозичити і закріпити у відповідному законодавстві України.

Впровадження та комерціалізація конкурентоспроможних передових технологій, ефективний технологічний обмін розширить можливості високотехнологічного імпорту та експорту, сприятиме запровадженню єдиних високих стандартів економічного розвитку та налагодженню співробітництва у цій сфері між Україною та передовими країнами світу.

Підвищена увага до цих правовідносин зумовлена також міжнародними зобов'язаннями України, зокрема підписанням 27 червня 2014 року Угоди про асоціацію між Україною, з однієї сторони, та Європейським Союзом, Європейським співтовариством 3 атомної енергії і їхніми державами-членами, з іншої сторони (далі - Угода про асоціацію між Україною та СС) [1]. Обраний Україною шлях інтеграції в $\mathrm{CC}$ потребує максимального наближення національного законодавства до законодавств країн-членів СС. Актуальність розв'язання цього питання є очевидною, оскільки це дозволить визначити конкретні заходи, які сприятимуть вступу України в Свропейський союз.

Науково-практичні аспекти трансферу технологій досліджені та відображені у багатьох наукових працях вітчизняних вчених, у тому числі фахівців з права інтелектуальної власності: Г. О. Андрощука, Ю. Л. Бошицького, В. І. Довбенко, Ю. М. Капіци, О. В. Кам'янської, В. М. Крижної, Н. С. Кузнєцової, В. В. Луця, О. П. Орлюк, Б. М. Падучака, Р. Б. Шишки та інших. Проте незважаючи на значний внесок вітчизняних науковців у розробку цієї тематики, багато питань досі залишаються недостатньо висвітленими. Так, наявні напрацювання не в повному обсязі охоплюють усі питання впровадження в Україні нових технологічних і технічних рішень, зокрема в умовах євроінтеграції. Кількість наукових праць, що безпосередньо стосуються пошуку механізмів для вдосконалення законодавства України у сфері трансферу технологій до рівня європейських стандартів, є водночас широкою і недостатньою. На погляд автора статті, подальшого дослід- 
ження потребують, насамперед, практичні рекомендації щодо пошуку механізмів, спрямованих на впровадження нових технологічних і технічних рішень, сучасних виробничих процесів, здатних випускати конкурентоспроможні товари, що дозволить економіці України вийти із затяжної кризи, а підприємствам та бізнесу збалансовано працювати в умовах ринкової економіки. Передусім це обумовлюється новизною даної проблеми. Недостатньо досліджені механізми наближення законодавства України до законодавства ЄС у сфері промислової власності 3 урахуванням вимог міжнародних договорів, що укладалися між $Є С$ та Україною. Тож, можна зробити висновок, що завдання розробити теоретичні аспекти та практичні дієві механізми із врегулювання в Україні цивільно-правових відносин щодо удосконалення законодавства у сфері трансферу технологій є актуальним.

Отже, метою статті є обгрунтування пропозицій, спрямованих на удосконалення законодавства України у сфері трансферу технологій 3 урахуванням європейського досвіду у цій сфері.

Для досягнення зазначеної мети були поставлені такі основні завдання:

- обгрунтувати проблематику дослідження та встановити ії чинники;

- вивчити досвід регулювання сфери трансферу технологій в європейських країнах та окремих технологічно розвинутих країн світу, визначити доцільність його запозичень для врегулювання даних відносин в Україні;

- з'ясувати проблемні питання комерціалізації об'єктів промислової власності, виявити суперечності та прогалини законодавства України у сфері трансферу технологій;

- обгрунтувати пропозиції та рекомендації з удосконалення механізму наближення законодавства України до законодавства СС у сфері трансферу технологій та визначити основні напрямки змін законодавства України з використання об'єктів промислової власності відповідно до європейських стандартів.

Для досягнення наукової об'єктивності результатів статті було використано комплекс методів дослідження, які застосовуються в сучасній юридичній науці. В роботі використані діалектичний, формально-логічний, історичний, порівняльно-правовий, формально-юридичний, системно-логічний методи дослідження та інші наукові методи дослідження правових явищ. 


\section{2. Досвід свропейських країн у сфері трансферу технологій}

Європейські країни - це країни з розвиненою ринковою економікою, які успішно використовують трансфер технологій для врегулювання відносин між наукою та промисловістю. Саме тому пропонується проаналізувати досвід законодавства ЄС у сфері трансферу технологій.

Наразі для України в цілях інноваційного розвитку, євроінтеграції, виконання вимог Угоди про асоціацію між Україною та СС актуальним є питання вивчення досвіду регламентації сфери трансферу технологій в ЄС. Аналіз нормативно-правових актів СС у сфері наукових досліджень дозволяє виявити пріоритетні напрямки розвитку сучасної інноваційної діяльності, серед яких формування єдиного правового простору та ринку високотехнологічної продукції.

Так, на початку 80-х років європейські країни відставали у сфері наукових досліджень та інновацій від таких передових країн світу як США та Японія. Серед основних причин відзначають відсутність загальної науково-технічної політики країн Європи, а також слабку інтегрованість окремих сегментів національних інноваційних систем [2, c. 86-90].

3 метою забезпечення відповідності пріоритетних напрямів науково-технічного та інноваційного розвитку ЄС сучасним темпам розробки і впровадження нових технологій на Лісабонській зустрічі у березні 2000 р. прийнято робочу стратегію економічного оновлення під назвою «Свропейська наукова сфера досліджень» (далі - Лісабонська стратегія) [3].

На виконання Лісабонської стратегії Європейською комісією було започатковано розробку великого проєкту, спрямованого на підтримку конкурентоспроможності Свропи стосовно США та Японії. Проєкт мав здійснюватися паралельно з рамковими програмами і визначати стратегію розвитку Європи на найближче десятиріччя, а також забезпечувати відкритий спільний інформаційний простір ЄС та його використання всіма зацікавленими особами, зокрема науковцями та фахівцями в інноваційній сфері $[4$, с. 85$]$.

Політика ЄС здійснювалася на основі визначених принципів: взаємної допомоги, максимальної консолідації зусиль і концентрації наявних ресурсів усіх країн-членів; спільного фінансування, згідно 3 
яким усі проєкти фінансують усі країни-члени $\mathrm{CC}$; загальності, який передбачає максимальну мобілізацію можливостей усіх учасників науково-інноваційної діяльності; фінансування інвестиційних проєктів, що дозволяє створити необхідну матеріальну базу для вільного творчого наукового пошуку.

У контексті цих регулятивних принципів визначалися основні напрямки науково-технічної стратегії $\mathrm{CC}$ : 1) нарощування розмірів фінансування наукових програм інноваційного розвитку; 2) інноваційно-технологічна модернізація неконкурентоспроможних галузей виробництва; 3) визначення першорядним розвиток найновітніших, наукомістких галузей; 4) посилення міжрегіонального та внутрішньорегіонального співробітництва в наукових дослідженнях та інноваційних технологіях, вироблення спільної політики їх розвитку; 5) максимальне сприяння розповсюдженню інновацій в межах $\mathrm{CC}$; 6) створення загальноєвропейського інформаційного середовища та єдиного наукового простору; 7) посилення уваги до фундаментальних наукових досліджень як фундаменту прикладних знань та інноваційних технологій; 8) підготовка висококваліфікованих наукових кадрів, спроможних забезпечити стабільний науково-технологічний прогрес усіх країн-членів СС [5, с. 347].

Таким чином, результатом реалізації Лісабонської стратегії в європейських країнах мало бути досягнення рекордних темпів економічного розвитку, цілковита зайнятість населення і максимальна соціальна справедливість. Для стимулювання розвитку економік в країнах-членах $\mathrm{CC}$ під час реалізації Лісабонської стратегії виникла необхідність у збільшенні фінансування наукових досліджень, особливо в галузі інформаційно-комунікативних технологій [6]. Проте через фінансово-економічну кризу 2008-2009 рр. наміченої цілі Лісабонської стратегії не було досягнуто.

3 метою консолідації зусиль виходу з кризи і створення умов для стійкого розвитку країн-членів СС було розроблено нову європейську стратегію економічного росту на 10 років - «Європа 2020: стратегія розумного, сталого і всеохоплюючого росту» (2010р.) [7]. Зважаючи на невдалу реалізацію багатьох ключових завдань Лісабонської стратегії, заходи нової стратегії доповнилися положеннями національних програмних реформ. 
Також для розвитку інноваційної діяльності та впровадження результатів НДДКР Комісією СС було прийнято ряд документів, у яких врегульовані механізми реалізації державної політики у сфері наукових досліджень та порядок надання державних асигнувань суб' єктам, які здійснюють комерціалізацію НДДКР, що фінансувалися або розроблялися за кошти державного бюджету. Поштовхом до формування державної політики ЄС у сфері нанотехнологій стало комюніке Комісії $€ \mathrm{C}$ «На шляху до європейської стратегії нанотехнологій» (2004 р.) [8], в якому розроблена стратегія розвитку та врегулювання цієї сфери. Наступним кроком став План дій ЄС у сфері нанотехнологій на 2005-2009 роки «Нанонауки і нанотехнології» [9], у якому було визначено низку чітких, взаємопов'язаних заходів з реалізації стратегії безпечних, надійних нанотехнологій. Для посилення інноваційних процесів і забезпечення економічної конкурентоспроможності ЄС було прийнято «Інноваційну стратегію» (2006 р.).

Можна стверджувати, що сучасна політика ЄС, спрямована на синхронізацію фундаментальних і прикладних досліджень з реальним впровадженням розробок, є доволі аргументованою і цілком виправданою. Вона сприятиме розвиткові науки як системи теоретичного знання й основи прикладних технологічних досліджень і інновацій. Сучасна політика ЄС у сфері наукових досліджень та інновацій $є$ конструктивною і перспективною, сприяє формуванню та розвитку інформаційного суспільства знань [5, с. 351].

Найсуттєвішим інструментом реалізації стратегії розвитку ЄС і його політики у сфері інноваційної діяльності також є багаторічні Рамкові програми підтримки наукових досліджень та інновацій. Кожна програма визначає: основні цілі науково-технічної діяльності, правила і механізми реалізації конкретних проєктів, бюджет і порядок розподілу коштів між різними програмами, комплекс інструментів для досягнення цілей.

Таким чином, одним зі основних механізмів реалізації політики стимулювання інноваційних науково-технологічних процесів є розробка i впровадження рамкових програм, спрямованих на формування цілісного європейського дослідницького простору без галузевого поділу, але з концентрацією на пріоритетних напрямках. В умовах глобалізації такий підхід дозволяє країнам-членам ЄС мати високий рівень кон- 
курентоздатності економіки, а взаємна інтеграція в рамках ЄС сприяє розвитку партнерських взаємовідносин між країнами та використанню об'єднаного інноваційного та науково-технічного потенціалу.

Так, 11 грудня 2013 року Європейський Парламент і Рада прийняли Регламент № 1291/2013/СС про створення нової Програми СС 3 досліджень та інновацій «Горизонт 2020 - Рамкова програма $з$ досліджень та інновацій» (2014-2020) (далі - Горизонт 2020). Основним завданням програми Горизонт 2020 є стимулювання передової науки, підтримка лідерства в промисловості, зміцнення конкурентоспроможності Європи у глобальному вимірі, iї економічного зростання та створення нових робочих місць. У 2015 році між Україною та ЄС була підписана Угода про участь України у програмі СС Горизонт 2020 [10].

Отже, Україна стала асоційованим членом найбільшої Рамкової програми ЄС 3 досліджень та інновацій Горизонт 2020 із загальним бюджетом близько 80 мільярдів євро, яка розрахована на 2014-2020 роки. Дане членство надало українським учасникам рівноправний статус з їхніми європейськими партнерами, а також відкрило можливості впливу на формування змісту цієї програми. Підписання Угоди про участь України у програмі ЄС Горизонт 2020 сприяє розширенню участі українських науково-дослідних організацій та університетів в європейських наукових дослідженнях, а також розвитку партнерських взаємовідносин між Україною та ЄС.

\section{3. Врегулювання в Україні відносин у сфері трансферу технологій}

3 перших же років незалежності в Україні багато уваги приділяється пріоритетним напрямам розвитку наукової та науково-технологічної діяльності, підходи та норми до яких містяться, зокрема, у Законах України: «Про наукову і науково-технічну діяльність» [11], «Про пріоритетні напрями розвитку науки і техніки» [12], «Про пріоритетні напрями інноваційної діяльності в Україні» [13], «Про державне регулювання діяльності у сфері трансферу технологій» [14] та інших нормативно-правових актах, що регулюють відносини у цій сфері. Проте протягом останніх років законами України про державний бюджет України постійно блокуються норми стосовно фінансового забезпечення наукової, науково-технічної сфери, зокрема, ч. 3 ст. 34 Закону України «Про наукову і науково-технічну діяльність», а також ство- 
рення пільгових умов для розвитку інноваційних процесів. В наслідок цього, розвиток інноваційної діяльності в Україні суттєво стримується через хронічне недофінансування даної галузі. Крім того, вагомою перешкодою для впровадження інноваційної продукції на підприємствах залишається значна зношеність технологічного обладнання, яке не може бути пристосоване до сучасних інноваційних технологій. Також однією із причин незацікавленості керівників підприємств у впровадженні нових технологій є відсутність дієвого механізму ефективного просування інновацій у виробництво та невирішеність низки правових, фінансових, організаційних, економічних питань щодо інноваційного розвитку на державному рівні.

Зокрема, у Франції питаннями трансферу результатів науково-технічної діяльності, створених за бюджетні кошти, займається Національне агентство з підвищення інноваційної привабливості наукових досліджень, яке було створене у 1979 р. $з$ метою сприяння інноваційній діяльності промисловості, насамперед, у сфері середнього і малого бізнесу. Дане Національне агентство здійснює фінансову підтримку інноваційних підприємств і науково-дослідних лабораторій. Однією із форм підтримки є надання безпроцентної позики на строк до 6 років в розмірі $50 \%$ від вартості проєкту, яка підлягає поверненню лише у випадку, якщо профінансований інноваційний проєкт виявиться успішним. Також для реалізації інноваційних програм можна отримати субсидії, гранти, дотації. Будь-яка форма фінансування орієнтована на стимулювання активізації участі малих і середніх підприємств у рамках регіональних або міжнародних програм. Автор статті вважає, що такий досвід Франції щодо підтримки державою інноваційних програм доцільно використати й в України.

В Україні державне регулювання діяльності щодо створення та впровадження технологій виконує уповноважений орган з питань формування та забезпечення реалізації державної політики у сфері трансферу технологій (далі - уповноважений орган з питань трансферу). Відповідно до п. 1 ст. 6 Закону України «Про державне регулювання діяльності у сфері трансферу технологій» основним завданням уповноваженого органу з питань трансферу є забезпечення формування державної політики щодо створення та впровадження технологій, набуття, охорони і захисту об'єктів права інтелектуальної власності, 
передачі майнових прав на технології та/або їх складові, створені 3 використанням бюджетних коштів. На підставі п. 3 ст. 6 даного Закону України уповноважений орган 3 питань трансферу подає Кабінету Міністрів України пропозиції щодо законодавчого стимулювання діяльності зі створення та впровадження високих технологій. Проте автор статті погоджується з науковцями [15, с. 121], що серед факторів, які гальмують освоєння новацій у промисловості, слід передусім назвати брак власних фінансових ресурсів, високі відсоткові ставки кредитів банків, зменшення внутрішнього попиту на продукцію вітчизняних виробників та значний ризик упродовж iї освоєння. Слабкою ланкою економічно-правового механізму управління національною економікою все ще залишається неспроможність держави забезпечити зростання впливу науки та нових технологій на ії̈ соціально-економічний розвиток.

Отже, застосовуючи європейський досвід щодо реалізації інноваційних програм в Україні та підвищення міжнародної конкурентоздатності нашої країни необхідно, перш за все, на державному рівні створити привабливі економічні умови у сфері передачі інноваційних технологій. Зокрема, змінити систему оподатковування, експортно-імпортну політику для сприяння концентрації інвестиційного капіталу та стимулювання фундаментальних і пошукових науково-дослідних робіт через цільові пільгові кредити, субсидії, дотації, дослідницькі контракти тощо. Необхідно удосконалити правову базу щодо фінансового забезпечення трансферу технологій.

Для активного впровадження результатів наукової та науково-технічної діяльності в економіку України має бути сформована інноваційна політика, що включає форми та методи державного стимулювання науково-технічної активності, активізації взаємодії науки i виробництва з метою широкого втілення розроблень в кінцевий виробничий результат - нові конкурентоспроможні види продукції, організаційні рішення, технологічні процеси. Така політика повинна передбачати вдосконалення правової, соціальної-економічної, організаційної, інформаційної бази та інших складових інноваційної діяльності.

Стратегічним напрямом соціально-економічної політики в Україні має стати використання інноваційних важелів людського розвитку. Соціальні інвестиції здатні забезпечити нову якість розвитку країни 
шляхом покращення соціально-психологічного й морального здоров'я нації. Забезпечення людського розвитку, розширення прав і свобод громадян, наближення до кращих світових стандартів якості життя потребує широкого впровадження соціальних інновацій в усіх сферах.

Наступним проблемним питанням у сфері трансферу технологій $€$ недосконалість механізму впровадження технологій, який повинен мати за мету безперервне масштабне оновлення виробництва. Автор статті вважає за доцільне на підприємствах, в наукових установах, організаціях та вищих навчальних закладах, що створюють та/або використовують технології, заснувати структурні підрозділи 3 питань формування та забезпечення реалізації державної політики у сфері трансферу технологій (далі - Центр трансферу технологій), які будуть займатися комерціалізацією об'єктів технології та ефективним управлінням інтелектуальною власністю. Безперечно, нині економіка потребує інтенсивного розвитку сфери трансферу. Сучасні технології повинні своєчасно передаватися у сферу бізнесу з тим, щоб забезпечити високу ефективність виробництва та своєчасну появу на ринку нових конкурентоспроможних товарів.

Розглянемо досвід провідних країн світу у сфері передачі та впровадження технологій. Для вивчення позитивної практики, пропонується спочатку детальніше розглянути досвід однісї з розвинених країн світу - США. На думку автора статті, саме досвід США щодо механізму впровадження технологій у структуру державного господарювання є найбільш цікавим для України.

На початку 90-х років XX ст. у США було сформовано мережу передачі технологій, що складається 3 головного національного i шістьох регіональних центрів, розташованих у різних частинах країни. Загальне керівництво роботою здійснює Національне агентство 3 дослідження космічного простору (NASA). Створена мережа має федеральне значення та надає необхідну допомогу у передачі технологій всім іншим зацікавленим відомствам. Усе це сприяє активізації діяльності щодо створення й передачі технологій на всіх рівнях.

У Німеччині функції посередників між науковими лабораторіями та промисловими компаніями з передачі технологій виконують спеціальні наукові товариства та спільні дослідницькі асоціації. Їх діяльність фінансується шляхом отримання субсидій федерального уряду i 
доходів від виконання контрактних досліджень. Також вагому участь в організації передачі технологій приймають місцеві органи влади. Зокрема, вони вносять великий внесок у створення наукових парків та інноваційних центрів, розглядаючи цю діяльність як один із найважливіших напрямків регіонального розвитку.

Безумовний інтерес щодо створення центрів трансферу технологій представляє Японія. Так, Японія приступила до реорганізації систем трансферу технологій у 1998 р., після прийняття законодавчого акта, що передбачає створення при університетах центрів з трансферу технологій, які надають винахідникам послуги з управління та комерціалізації результатів досліджень і розроблень.

Центри займаються передачею патентних прав на об'єкти промислової власності, які були створені в національних університетах та державних наукових організаціях. Однак досвід їх діяльності показав, що коштів, наданих урядом, недостатньо для ефективного здійснення трансферу технологій. Ці організації створили нові асоційовані комерційні компанії для надання сприяння комерціалізації результатів університетських досліджень і розроблень, а також звернулися до професорсько-викладацького складу з проханням інвестувати кошти у зазначені компанії. Але і ці заходи не забезпечували повної фінансової незалежності. Тому у 2004 році японський уряд надав всім національним університетам незалежний юридичний статус з тим, щоб університети могли взяти участь в ініціативах, пов'язаних зі створенням центрів трансферу технологій [15, с. 122-123].

Застосовуючи досвід провідних країн світу у сфері передачі технологій, пропонуємо в Україні на підприємствах, в наукових установах, в організаціях та вищих навчальних закладах, що створюють та/ або використовують технології та/або їх складові і яким належать або передаються майнові права на використання об'єктів права інтелектуальної власності, що є складовими технологій, створити спеціальні Центри трансферу технологій, які мають займатися комерціалізацією технології та/або іiі складових та ефективним управлінням інтелектуальною власністю, зокрема: виявляти та оцінювати комерційний потенціал технології та/або іiі складових; вчиняти дії з набуття та охорони прав на технологію та/або їі складові; визначати найбільш ефективні шляхи використання і трансферу зазначеної технології; залучати 
інвестиції у сферу трансферу технологій, сприяти встановленню нових ділових контактів між розробниками нововведень та їх споживачами; виплачувати винагороду авторам технологій та/або об'єктів права інтелектуальної власності після їх трансферу та укладати договори про передачу технологій; проводити аукціони та виставкові заходи у сфері науково-технічної та інноваційної діяльності з метою підтримки вітчизняних виробників високотехнологічної продукції та пошуку нових споживачів; сприяти міжнародній співпраці у сфері трансферу технологій шляхом проведення конференцій з інноваційної тематики.

Отже, механізмами, що забезпечують взаємозв'язок науки і виробництва, можуть стати спеціальні структурні підрозділи - Центри трансферу технологій, які повинні створюватися за активної законодавчої та фінансової участі держави. Варто відновити податкові пільги розробникам та підприємствам, які впроваджують нові технології.

Другим кроком має стати участь держави у фінансуванні інноваційного процесу та максимальне полегшення доступу малого та середнього бізнесу до державних фінансових ресурсів. Доцільно застосовувати такі інструменти, як довгостроковий лізинг обладнання та державні замовлення. Також необхідно розробити методику оцінки ефективності дієвих програм фінансування НДДКР і порівнювати величину витрат на фінансування з результативністю науково-дослідної діяльності.

Потрібно також вивчити позитивний досвід країн ближнього закордоння, як на законодавчому рівні вирішити проблемне питання обов'язкового впровадження результатів НДДКР, створених повністю або частково за бюджетні кошти. Так, наприклад, у Республіці Білорусь основним нормативним актом, що регулює питання комерціалізації результатів НДДКР, створених повністю або частково за бюджетні кошти, є Указ Президента Республіки Білорусь від 4 лютого 2013 р. «Про комерціалізацію результатів наукової та науково-технічної діяльності, створених за державні кошти» [16]. Указом встановлено, що результати наукової та науково-технічної діяльності, створені повністю або частково за кошти республіканського і (або) місцевих бюджетів, у тому числі державних цільових бюджетних фондів, а також державних позабюджетних фондів, підлягають обов'язковій комерціалізації в порядку і строки, передбачені Указом. 
Комерціалізація результатів наукової та науково-технічної діяльності забезпечується державними замовниками і здійснюється володільцем майнових прав на ці результати протягом трьох років після їх створення. У випадках надання результатам наукової та науково-технічної діяльності правової охорони як об'єктам права - протягом трьох років з дня отримання охоронного документа.

Автор статті пропонує застосувати позитивний досвід Республіки Білорусь щодо обов'язкового впровадження результатів наукової та науково-технічної діяльності, створених за рахунок бюджетних коштів та внести відповідні доповнення в ч. 5 ст. 11 «Порядок передачі майнових прав на технології» Закону України «Про державне регулювання діяльності у сфері трансферу технологій». Таким чином, особи, які набувають майнові права на технологію та/або ії̈ складові, що створені у процесі виконання НДДКР, які фінансуються за рахунок бюджетних коштів, повинні здійснювати в обов'язковому порядку трансфер і цей обов'язок має бути закріплений на законодавчому рівні.

Аналізуючи досвід України та провідних країн світу у сфері трансферу інноваційних технологій та/або іiі складових у промисловість, слід зазначити, що лише активна участь держави у створенні відповідних центрів з трансферу технологій як на законодавчому рівні, так і за допомогою довгострокового фінансування, а також податкова підтримка розробникам інновацій та споживачам, які проводять впровадження технологій та/або іiі складових, може вирішити проблемні питання активізації інноваційних процесів.

Також безумовно, найпоширенішими каналами трансферу технологій сьогодні $є$ міжнародна торгівля, яка відіграє ключову роль у комерційному трансфері, наукомісткий сервіс у вигляді надання професійних послуг у сфері виробництва, обігу й управління (інжиніринг, консалтинг); міжнародне науково-технічне співробітництво; комплексний трансфер технологій. Проте, на відміну від практики технологічно розвинутих країн, в Україні трансфер технологій поки що не отримав необхідного розвитку. Тому Україні як державі, що зберегла значний науково-технічний потенціал, в найкоротший строк необхідно освоїти механізми комерціалізації результатів наукових досліджень та науково-технічних розробок і включити інтелектуальний продукт в ринковий оборот для того, щоб стати гідним учасником міжнародного співробітництва у сфері трансферу технологій. 
Підсумовуючи все сказане, автор статті пропонує наступний механізм з передачі технологій та/або ії складових. По-перше, у разі, якщо технологія та/або іiі складові, створені у процесі виконання науково-дослідних та дослідно-конструкторських робіт, які фінансуються за бюджетні кошти, то особа, яка буде мати майнові права на зазначену технологію, повинна здійснити обов'язковий трансфер технологій та/ або їх складових за фінансової підтримки держави протягом трьох років після створення даної технології та/або її складових.

По-друге, у разі, якщо до виконавця переходять майнові права на даний об'єкт права інтелектуальної власності, чи у випадку, коли технології та/або ії складові створені розробниками не за бюджетні кошти, то держава повинна створити привабливі економічні умови для розробників і споживачів щодо впровадження даної технології та/або іiі складових. Зокрема, змінити систему оподатковування, експортно-імпортну політику для сприяння концентрації інвестиційного капіталу та стимулювання фундаментальних і пошукових науково-дослідних робіт через цільові пільгові кредити, субсидії, дотації.

По-третє, держава має сприяти створенню на підприємствах незалежно від форм власності, в наукових установах, організаціях та вищих навчальних закладах, що створюють та/або використовують технології та/або їх складові і яким належать або передаються майнові права на використання об'єктів права інтелектуальної власності, що є складовими технологій спеціальних Центрів трансферу технологій, які мають займатися комерціалізацією технології та/ або її складових та ефективним управлінням інтелектуальною власністю. Зокрема, пропонується застосувати досвід провідних країн світу у сфері трансферу технологій, де діяльність зазначених Центрів фінансується за рахунок державних субсидій і доходів від виконання контрактних досліджень [17, с. 98-99].

Отже, для розвитку сфери трансферу технологій з метою підвищення міжнародної конкурентоздатності України необхідно удосконалити економіко-правову базу для забезпечення трансферу технологій шляхом внесення змін і доповнень у чинні законодавчі акти з метою створення привабливих соціально-економічних умов для передачі інноваційних технологій на державному рівні та забезпечення підтримки національного виробника. 


\section{4. Висновки}

У результаті дослідження, виконаного на основі аналізу нормативно-правових актів європейських країн та окремих провідних закордонних країн, практики застосування їх норм, чинного законодавства України у сфері трансферу технологій, а також теоретичного осмислення наукових праць фахівців з права промислової власності, автором запропоноване нове вирішення наукового завдання цивільного права, яке полягає у розробці теоретичних положень та практичних рекомендацій щодо використання об'єктів права промислової власності у сфері трансферу технологій та вдосконалення механізму законодавчого регулювання трансферу технологій в Україні з урахуванням європейського досвіду у цій сфері.

1. Встановлено, що в Україні необхідними умовами активізації інноваційних процесів $є$ проведення комплексу заходів, важливе місце серед яких займає система трансферу технологій. Але негативні наслідки кризових явищ, які відбуваються в економіці України, та суттєве зменшення податкових пільг для трансферу технологій призвели до того, що в нашій державі помітно ускладнилось проведення наукових досліджень і розробок та впровадження нових технологій у виробництво.

2. Зроблено висновок, що в Україні закладено нормативну базу щодо міжнародного співробітництва у сфері трансферу технологій. Проте, на відміну від практики провідних країн світу, в нашій державі трансфер технологій поки що не отримав необхідного розвитку. Автор статті вважає, що для активного впровадження результатів наукової та науково-технічної діяльності в економіку України має бути, по-перше, сформована інноваційна політика, що включає форми та методи державного стимулювання науково-технічної активності, активізації взаємодії науки й виробництва $з$ метою широкого втілення розроблень в кінцевий виробничий результат - нові конкурентоспроможні види продукції, організаційні рішення, технологічні процеси. Така політика повинна передбачати вдосконалення правової, соціальної-економічної, організаційної, інформаційної бази та інших складових інноваційної діяльності. По-друге, державна політика у сфері передачі технологій недостатньою мірою націлена на розвиток малого і середнього бізнесу і це суперечить світовим тенденціям. 
3. Аналізуючи вітчизняний досвід та досвід європейських країн у сфері трансферу інноваційних технологій та/або ії складових у промисловість, слід зазначити, що лише активна участь держави у створенні відповідних центрів з трансферу технологій як на законодавчому рівні, так і за допомогою довгострокового фінансування, а також податкова підтримка розробникам інновацій та споживачам, які проводять впровадження технологій та/або іiі складових, може вирішити проблемні питання активізації інноваційних процесів.

4. Доведено, що у разі, якщо технологія та/або їі складові, створені у процесі виконання науково-дослідних та дослідно-конструкторських робіт, які фінансуються за бюджетні кошти, то особа, яка буде мати майнові права на зазначену технологію, повинна здійснити обов'язковий трансфер технологій та/або їх складових за фінансової підтримки держави протягом трьох років після створення даної технології та/або іiі складових. Тому пропонуємо застосувати позитивний досвід Республіки Білорусь щодо обов'язкової комерціалізації результатів наукової та науково-технічної діяльності, створених за бюджетні кошти, та внести відповідні доповнення в ч. 5 ст. 11 Закону України «Про державне регулювання діяльності у сфері трансферу технологій».

Автор статті вважає, що особи, які набувають майнові права на технологію та/або іiі складові, що створені у процесі виконання науково-дослідних та дослідно-конструкторських робіт, які фінансуються за рахунок бюджетних коштів, повинні здійснювати в обов'язковому порядку трансфер і цей обов'язок має бути закріплений на законодавчому рівні.

У разі, якщо до виконавця переходять майнові права на даний об'єкт права інтелектуальної власності, чи у випадку, коли технології та/або іiі складові створені розробниками не за бюджетні кошти, то держава повинна створити привабливі економічні умови для розробників і споживачів щодо впровадження даної технології та/або іiї складових. Зокрема, змінити систему оподатковування, експортно-імпортну політику для сприяння концентрації інвестиційного капіталу та стимулювання фундаментальних і пошукових науково-дослідних робіт через цільові пільгові кредити, субсидії, дотації тощо.

5. Обгрунтовано, що держава має сприяти створенню спеціальних Центрів трансферу технологій на підприємствах, у наукових устано- 
вах, в організаціях, у вищих навчальних закладах, що створюють та/ або використовують технології та/або їх складові і яким належать або передаються майнові права на використання об'єктів права інтелектуальної власності, що є складовими технологій. Дані Центри мають займатися комерціалізацією технології та/або ії̈ складових та ефективним управлінням інтелектуальною власністю. Зокрема, пропонуємо застосувати досвід провідних країн світу у сфері трансферу технологій, де діяльність зазначених Центрів фінансується шляхом отримання державних субсидій і доходів від виконання контрактних досліджень.

6. Аналіз нормативно-правових актів ЄС у сфері наукових досліджень дозволяє виявити пріоритетні напрямки розвитку сучасної інноваційної діяльності, серед яких формування єдиного економіко-правового простору та ринку високотехнологічної продукції. Сучасна політика $\mathrm{CC}$, спрямована на синхронізацію фундаментальних і прикладних досліджень 3 реальним впровадженням розробок, $є$ доволі аргументованою і цілком виправданою. Вона сприятиме розвиткові науки як системи теоретичного знання й основи прикладних інноваційних досліджень і технологічних розробок.

7. Встановлено, що в ЄС одним з основних механізмів реалізації політики стимулювання інноваційних науково-технологічних процесів $є$ розробка і впровадження рамкових програм, спрямованих на формування цілісного європейського дослідницького простору без галузевого поділу, але з концентрацією на пріоритетних напрямках. В умовах глобалізації такий підхід дозволяє країнам-членам СС мати високий рівень конкурентоздатності економіки, а взаємна інтеграція в рамках $Є С$ сприяє розвитку партнерських взаємовідносин між країнами та використанню об'єднаного інноваційного та науково-технічного потенціалу.

Нині Україна стала асоційованим членом найбільшої Рамкової програми СС $з$ досліджень та інновацій «Горизонт 2020». Дане членство надало українським учасникам рівноправний статус з їхніми європейськими партнерами. Підписання Угоди про участь України у програмі ЄС «Горизонт 2020» сприяє розширенню участі українських науково-дослідних організацій та університетів в європейських наукових дослідженнях, а також розвитку партнерських взаємовідносин між Україною та СС. 


\section{Список літератури:}

1. Угода про асоціацію між Україною, з однієї сторони, та Європейським Союзом, Європейським Співтовариством 3 атомної енергії і їхніми державами-членами, 3 іншої сторони: ратифікована 16 вересня 2014 року Верховною Радою України та Європейський парламентом / Міжнародний документ. Офіиійний вісник Украӥни. 2014. № 75, Т 1. Ст. 2125. URL: http://zakon5.rada.gov.ua/laws/show/984_011

2. Ярошевська Т. В. Аналіз законодавства СС та окремих технологічно розвинених країн у сфері трансферу технологій. Електронне наукове фахове видання. Юридичний науковий електронний журнал. 2015. № 3. С. 86-90. URL: http://lsej.org.ua/3_2015/3_2015.pdf.

3. Lisbon European Council 23-24 March 2000 / Presidency Conclusions. URL: http://consslium.europa.eu/eudocs/cmsdata/docs/pressdata/en/ec/00100 r1.en0.htm

4. Інформаційне забезпечення інноваційного розвитку: світовий та вітчизняний досвід : монографія / Т. В. Писаренко, Т. К. Кваша, Н. В. Березняк, О. В. Прудка. Київ : УкрINTEL, 2015. 239 с.

5. Чорногор Я. О. Інноваційний розвиток країн $Є С$ в умовах глобалізації. Сучасна українська політика. Політики $і$ політологи про неї. 2009. Вип. 18. С. $344-352$.

6. Зубченко Л. Лиссабонская стратегия Евросоюза: разочарование и надежды. Перспективы. Фонд исторической перспективы. URL: http://www.perspektivy.info/oykumena/europe/lissabonskaja_strategija jevrosojuza_razocharovanija_i_nadezhdy_2007-09-26.htm

7. European Commission. Communication from the Commission Europe 2020: A strategy for smart, sustainable and inclusive growth. COM(2010) 2020 final. URL: https://www.eea.europa.eu/policy-documents/com-2010-2020-europe-2020

8. Towards a European Strategy for Nanotechnology. Luxembourg: Office for Official Publications of the European Communities, 2004. 24 p.

9. Nanosciences and nanotechnologies: An action plan for Europe 2005-2009. URL: https://ec.europa.eu/research/industrial_technologies/pdf/policy/action_plan_ brochure_en.pdf

10. Угода між Україною і Європейським Союзом про участь України у програмі Європейського Союзу Горизонт 2020 - Рамкова програма 3 досліджень та інновацій (2014-2020) від 03 березня 2015 р. № 984_018. URL: http://zakon3.rada.gov.ua/laws/show/984 018

11. Про наукову і науково-технічну діяльність: Закон України від 13 грудня 1991 р. № 1977-XII / Верховна Рада України. Відомості Верховної Ради України. 1992. № 12. Ст. 165.

12. Про пріоритетні напрями розвитку науки і техніки: Закон України від 11 липня 2001 р. № 2623-ІІІ / Верховна Рада України. Відомості Верховної Ради України. 2001. № 48. Ст. 253.

13. Про пріоритетні напрями інноваційної діяльності в Україні: Закон України від 16 січня 2003 р. № 433-IV / Верховна Рада України. Відомості Верховної Ради України. 2003. № 13. Ст. 93. 
14. Про державне регулювання діяльності у сфері трансферу технологій: Закон України від 14 вересня 2006 р. № 143-V / Верховна Рада України. Відомості Верховної Ради України. 2006. № 45. Ст. 434.

15. Нагорняк Г. С., Нагорняк І. С., Вовк Ю. Я. Вплив трансферу технологій на інноваційні процеси: український та зарубіжний досвід. Соціальноекономічні проблеми і держава. 2013. № 2. С. 117-127.

16. Про комерціалізацію результатів наукової та науково-технічної діяльності, створених за рахунок державних коштів: Указ Президента Республіки Білорусь від 4 лютого 2013 року № 59. URL: http://www.gknt.gov.by/opencms/ opencms/ru/zakon/z2/

17. Ярошевська Т. В. Удосконалення механізмів врегулювання правовідносин у сфері трансферу технологій. Актуальні проблеми вітчизняної юриспрудениії. 2018. № 3. С. 95-99.

\section{References:}

1. Ofitsiinyi visnyk Ukrainy (2014) Uhoda pro asotsiatsiiu mizh Ukrainoiu, $z$ odniiei storony, ta Yevropeiskym Soiuzom, Yevropeiskym Spivtovarystvom z atomnoi enerhii $i$ yikhnimy derzhavamy-chlenamy, $z$ inshoi storony: ratyfikovana 16 veresnia 2014 roku Verkhovnoiu Radoiu Ukrainy ta Yevropeiskyi parlamentom / Mizhnarodnyi dokument [Association Agreement between the European Union and the European Atomic Energy Community and their Member States, of the one part, and Ukraine, of the other part: ratified on 16 September 2014 by the Verkhovna Rada of Ukraine and the European Parliament / International document]. Ofitsiinyi visnyk Ukrainy [Official Bulletin of Ukraine], vol. 1, no. 75, pp. 21-25.

2. Yaroshevska, T. V. (2015). Analiz zakonodavstva YeS ta okremykh tekhnolohichno rozvynenykh krain u sferi transferu tekhnolohii [Analysis of the EU and certain technologically developed foreign countries legislation in the sphere of a transfer of technologies]. Elektronne naukove fakhove vydannia «Yurydychnyi naukovyi elektronnyi zhurnal» [The electronic scientific professional edition «Legal scientific e-journal»] (electronic journal), no. 3, pp. 86-90. Retrieved from: http://lsej.org.ua/3_2015/3_2015.pdf(accessed 11 May 2020).

3. The European Council (2000). The Lisbon European Council 23 And 24 March 2000 Presidency Conclusions. The European Parliament. Retrieved from: https://www.europarl.europa.eu/summits/lis1_en.htm (accessed 11 May 2020).

4. Pysarenko, T. V., Kvasha, T. K., Berezniak, N. V., Prudka, O. V. (2015). Informatsiine zabezpechennia innovatsiinoho rozvytku: svitovyi ta vitchyznianyi dosvid: monohrafia [Information support of innovative development: world and domestic experience: monograph]. Kyiv: UkrINTEL, 239 p.

5. Chornohor, Ya. O. (2009). Innovatsiinyi rozvytok krain YeS v umovakh hlobalizatsii [Innovative development of EU countries in the context of globalization]. Suchasna ukrainska polityka. Polityky i politolohy pro nei [Modern Ukrainian politics. Politicians and political scientists about it] (electronic journal), no. 18, pp. 344-352. Retrieved from: http://dspace.nbuv.gov.ua/handle/123456789/13734 (accessed 11 May 2020). 
6. Zubchenko, L. (2007). Lissabonskaya strategiya Evrosoyuza: razocharovanie i nadezhdy [The European Union's Lisbon strategy: frustration and hope]. Perspektivy. Fond istoricheskoy perspektivy [Prospects. Fund of historical prospect] (electronic journal). Retrieved from: http://www.perspektivy.info/ oykumena/europe/lissabonskaja_strategija_jevrosojuza_razocharovanija_i_ nadezhdy_2007-09-26.htm (accessed 11 May 2020).

7. The European Commission (2010). Communication from the Commission Europe 2020: A strategy for smart, sustainable and inclusive growth. COM(2010) 2020 final. The European Environment Agency. Retrieved from: https://www.eea.europa.eu/ policy-documents/com-2010-2020-europe-2020 (accessed 11 May 2020).

8. The European Commission (2004). Towards a European Strategy for Nanotechnology. Luxembourg: Office for Official Publications of the European Communities, $24 \mathrm{p}$.

9. The European Commission (2005). Nanosciences and nanotechnologies: An action plan for Europe 2005-2009. Luxembourg: Office for Official Publications of the European Communities, $14 \mathrm{p}$.

10. Verkhovna Rada Ukrainy (2015). Uhoda mizh Ukrainoiu $i$ Yevropeiskym Soiuzom pro uchast Ukrainy u prohrami Yevropeiskoho Soiuzu Horyzont 2020 Ramkova prohrama $z$ doslidzhen ta innovatsii (2014-2020) vid 03 bereznia $2015 \mathrm{r}$. [Agreement between Ukraine and the European Union on Ukraine's participation in the European Union programme Horizon 2020 - Framework Programme for Research and Innovation (2014-2020) of March 3, 2015]. Verkhovna Rada Ukrainy. Retrieved from: http://zakon3.rada.gov.ua/laws/show/984_018 (accessed 11 May 2020).

11. Verkhovna Rada Ukrainy (1992) Pro naukovu i naukovo-tekhnichnu diialnist: Zakon Ukrainy vid 13 hrudnia 1991 r. № 1977-XII [On scientific and scientific and technical activity: Law of Ukraine of December 13, 1991 no. 1977-XII]. Vidomosti Verkhovnoi Rady Ukrainy [Vidomosti of the Verkhovna Rada of Ukraine], no. 12 , p. 165.

12. Verkhovna Rada Ukrainy (2001). Pro priorytetni napriamy rozvytku nauky i tekhniky: Zakon Ukrainy vid 11 lypnia 2001 r. № 2623-III [On priority directions of science and technology development: Law of Ukraine of July 11, 2001, no. 2623-III]. Vidomosti Verkhovnoi Rady Ukrainy [Vidomosti of the Verkhovna Rada of Ukraine], no. 48 , p. 253.

13. Verkhovna Rada Ukrainy (2003). Pro priorytetni napriamy innovatsiinoi diialnosti v Ukraini: Zakon Ukrainy vid 16 sichnia 2003 r. № 433-IV [On priority directions of innovation activity in Ukraine: Law of Ukraine of January 16, 2003, no. 433-IV]. Vidomosti Verkhovnoi Rady Ukrainy [Vidomosti of the Verkhovna Rada of Ukraine], no. 13, p. 93.

14. Verkhovna Rada Ukrainy (2006). Pro derzhavne rehuliuvannia diialnosti u sferi transferu tekhnolohii: Zakon Ukrainy vid 14 veresnia 2006 r. № 143-V [On state regulation of activities in the field of technology transfer: Law of Ukraine of September 14, 2006 no. 143-V]. Vidomosti Verkhovnoi Rady Ukrainy [Vidomosti of the Verkhovna Rada of Ukraine], no. 45, p. 434.

15. Nahorniak, H. S., Nahorniak, I. S., Vovk, Yu. Ya. (2013). Vplyv transferu tekhnolohii na innovatsiini protsesy: ukrainskyi ta zarubizhnyi dosvid [The impact 
of technology transfer on innovation processes: Ukrainian and foreign experience]. Sotsialno-ekonomichni problemy $i$ derzhava [Socio-economic problems and the state], no. 2, pp. 117-127.

16. Natsional'nyy pravovoy Internet-portal Respubliki Belarus' (2013). O kommertsializatsii rezul'tatov nauchnoy I nauchno-tekhnicheskoy deyatel'nosti, sozdannykh za schet gosudarstvennykh sredstv: Ukaz Prezidenta Respubliki Belarus' ot 4 fevralya $2013 \mathrm{~g}$. № 59 [On the commercialization of the results of scientific and scientific-technical activity created at the expense of state funds: Decree of the President of the Republic of Belarus of February 4, 2013, no. 59]. Natsional'nyy pravovoy Internet-portal Respubliki Belarus' [The National Legal Internet Portal of the Republic of Belarus]. Retrieved from: http://uiip.bas-net.by/news/ukaz presid rb_04_02_2013_n59.pdf (accessed 11 May 2020).

17. Yaroshevska, T. V. (2018). Udoskonalennia mekhanizmiv vrehuliuvannia pravovidnosyn u sferi transferu tekhnolohii [An improvement of mechanisms of the regulation of legal relations in the sphere of technology transfer]. Aktualni problemy vitchyznianoi yurysprudentsii [Current problems of domestic jurisprudence], no. 3, pp. 95-99. 